\title{
Predictors of Current CD4+ T-Cell Count Among Women of Reproductive Age on Antiretroviral Therapy in Public Hospitals, Southwest Ethiopia
}

\author{
Alemayehu Sayih Belay (1D) \\ Gizachew Ayele Manaye (D) ${ }^{2}$ \\ Kindie Mitiku Kebede (iD ${ }^{3}$ \\ Dejene Derseh Abateneh (iD) ${ }^{4}$ \\ 'Mizan Tepi University, College of \\ Medicine and Health Sciences, \\ Department of Nursing, Mizan Aman, \\ Ethiopia; ${ }^{2}$ Mizan Tepi University, College \\ of Medicine and Health Sciences, \\ Department of Medical Laboratory \\ Sciences, Mizan Aman, Ethiopia; ${ }^{3}$ Mizan \\ Tepi University, College of Medicine and \\ Health Sciences, Department of Public \\ Health, Mizan Aman, Ethiopia; ${ }^{4}$ Kotebe \\ Metropolitan University, Menelik II \\ College of Medicine and Health Sciences, \\ Department of Medical Laboratory \\ Sciences, Addis Ababa, Ethiopia
}

Background: HIV/AIDS is one of the major global public health problems. CD4 is a glycoprotein found on the surface of different immune cells. CD4 cell counts determine the need for screening and prophylactic interventions against common opportunistic infections in those with advanced HIV disease. Thus, this study aimed to assess the predictors of current $\mathrm{CD}^{+}$T-cell count among women of reproductive age on antiretroviral therapy in public hospitals, southwest Ethiopia.

Methods: A cross-sectional study was conducted from February to April 2018. A total of 422 participants in the three public hospitals were selected using a systematic random sampling method. Linear regression analyses were used to determine the important predictors of current $\mathrm{CD}^{+}{ }^{+}$T-cell count at $\mathrm{p}$-values of $<0.05$.

Results: A total of 422 women with a median age of 37.00 years participated in this study. More than one in ten (12.8\%) respondents experienced immunological failure. An increased current $\mathrm{CD}^{+} \mathrm{T}$-cell count was observed among patients with a tertiary level of education $[\beta=$ $56.45,95 \%$ CI $(3.5,109.4)]$, baseline WHO clinical stage II $[\beta=44.06,95 \%$ CI $(5.3,82.9)]$, initial regimen of $\mathrm{AZT}+3 \mathrm{TC}+\mathrm{EFV}[\beta=167.23$, 95\% CI $(100.4,234.1)]$, with increased baseline $\mathrm{CD}^{+}$T-cell count $[\beta=0.35,95 \% \mathrm{CI}(0.2,0.5)]$, and with increased time duration on ART $[\beta=14.36,95 \%$ CI $(6.304,22.4)]$. On the other hand, the current CD4 ${ }^{+}$T-cell count was lowered among patients with poor baseline adherence, opportunistic infection, and viral load of $\geq 1000$ by 181.06 cells $/ \mathrm{mm}^{3}, 101.62$ cells $/ \mathrm{mm}^{3}$, and 137.53 cells $/ \mathrm{mm}^{3}$ compared to good baseline adherence, no opportunistic infection and undetectable viral load, respectively. Conclusion: The immunological failure was relatively low. Maintaining adherence, early identification and treatment of opportunistic infections, and minimizing viral load to undetectable levels may further decrease immunological failure.

Keywords: predictors, CD4+ T-cell count, women, reproductive age, antiretroviral therapy, Ethiopia

\section{Background}

Human immunodeficiency virus/acquired immunodeficiency syndrome (HIV/ AIDS) is one of the major public health problems. Globally, 75.7 million people have become infected with HIV since the start of epidemic up to the end of 2019, whereas 38.0 million people were living with HIV in 2019; of which 1.7 million people were newly infected. HIV/AIDS accounted for 32.7 million deaths from AIDS-related illnesses since the start of the epidemic. ${ }^{1}$

Since the start of the HIV epidemic globally, HIV-infected women in many regions, especially in South East Asia and sub-Saharan Africa, remained unduly
Correspondence: Alemayehu Sayih Belay Mizan Tepi University, College of Health Sciences, Department of Nursing, P.O. Box: 260, Mizan Teferi, Ethiopia

Tel $+25|-9||66986|$

Email Alex.sayihalem2018@gmail.com 
high because of vulnerabilities created by unequal cultural, social, and economic status. Globally, in 2019, an estimated 19.2 million women were living with HIV, constituting more than half of all adults aged 15 and over. $^{2}$

Women and girls in the sub-Saharan Africa region accounted for 59\% of all new HIV infections in 2019. Moreover, five in six new infections in this region were among adolescents aged 15-19 years. Low socioeconomic status, cultural stigmas, social barriers, insufficient health care facilities, limited health care professionals, and inadequate availability of health related information are the major contributing factors to the high prevalence and dis-

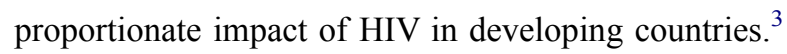

In Ethiopia, 1\% of adults aged 15-49 years were living with HIV in 2018. About 23,000 people were newly infected with HIV. Furthermore, 11,000 people were died from AIDS-related illnesses in the same year. ${ }^{4}$ Women were disproportionally affected by HIV in Ethiopia. For instance, 390,000 of the total 630,000 adults living with HIV were women in 2019. New HIV infections among young women (aged 15-24 years) were two times more than new HIV infections among young men (aged 15-24 years). ${ }^{5}$

Antiretroviral therapy (ART) drugs are recommended by the World Health Organization (WHO) to be given to all people with HIV. These reduce the amount of HIV in the body, stop the progression of HIV disease and decrease the morbidity and mortality related to HIV/AIDS. ${ }^{1,6}$ Even though there is no effective cure for HIV, it can be controlled with proper ART drug adherence. HIV treatment does not prevent the transmission of other sexually transmitted diseases. ${ }^{7}$

In 2015, according to the WHO's "universal test and treat" (UTT) strategy, ART should be initiated for all patients diagnosed with HIV irrespective of CD4 cell count. $^{8}$ The efficacy of ART is monitored by laboratory and clinical measures, including viral load (VL) and cluster of differentiation 4 (CD4) cell count, while on treatment. The World Health Organization recommends viral load estimation as the gold standard approach to diagnose and confirm treatment failure. ${ }^{9}$ However, poor adherence to $\mathrm{WHO}$ and national guidelines on VL testing, limited viral load testing machines, overburdened health care workers, and inefficient transport and delivery systems have been reported as major barriers for the implementations of VL testing in resource-limited countries. ${ }^{10,11}$ Also CD4 count is currently not recommended for monitoring purposes, it is applied to determine whether HIV patients develop advanced HIV diseases or not. ${ }^{12}$

According to the WHO, advanced HIV disease for adults, adolescents, and children $\geq$ five years is defined as a "CD4 cell count $<200$ cells $/ \mathrm{mm}^{3}$ or a WHO clinical stage 3 or 4 events at presentation for care". ${ }^{12}$ Worldwide, about one-third of all HIV-positive patients in active care are living with advanced HIV disease. These patients are more prone to develop opportunistic infections including severe bacterial infections, tuberculosis, and cryptococcal meningitis, which can result in an increased risk of morbidity and mortality. ${ }^{12,13}$

CD4 is a glycoprotein found on the surface of different immune cells such as $\mathrm{T}$ helper cells, monocytes, macrophages, and dendritic cells, ${ }^{14}$ and CD4 T-cell count is the most important marker or indicator of immune function in patients living with HIV. CD4 T-cell count remains the best predictor of morbidity and mortality in HIV-positive individuals. $^{12,15}$ It is one of the key determinants of the need for screening and prophylactic interventions against common opportunistic infections in those with advanced HIV disease, HIV-related malignancies, and immune reconstitution inflammatory syndrome (IRIS) following ART initiation and needing close clinical monitoring. ${ }^{10,12}$ Moreover, CD4 cell counts can help to identify patients in need of critical care and support diagnostic decisionmaking at baseline and in patients returning to care after a period of treatment interruption. ${ }^{16}$ It is also used to correlate the immunological classification of HIV infection with clinical staging of HIV-related diseases. ${ }^{17,18}$

There are different contributing factors which could have an effect on immunological failure and these turn to an increase in morbidity and mortality of women associated with advanced HIV disease. ${ }^{19,20}$ For instance, higher baseline $\mathrm{CD}^{+}$T-cell count, long duration on ART, younger age, patients from a military health care facility, good adherence, viral load suppression and early initiation of treatment contributed positively to the increment of the CD4 count. $^{21,22}$ Whereas, patients on ART regimen of 1e (TDF-3TC-EFV), $2 \mathrm{f}$ (AZT-3TC-ATV/r), and $2 \mathrm{~h}$ (TDF-3TC-ATV/r), and a viral load $>1000$ copies were negatively associated with recent CD4 count. ${ }^{21-23}$ Besides, factors like urban residency ${ }^{24}$ and white ethnicity were associated with increased CD4 count. ${ }^{25}$ Whereas old age, lower CD4 count at baseline, ${ }^{26}$ severe clinical-stage, tuberculosis (TB) coinfection, ${ }^{27}$ poor nutritional status, pregnancy, stress, smoking status, and drug use have been investigated as predictors of low CD4 count. ${ }^{28-30}$ 
Identification of factors affecting $\mathrm{CD} 4^{+} \mathrm{T}$-cell counts for HIV patients maybe plays an important role in their care program and their survival. ${ }^{31}$ Therefore, the findings of this study could be an input for policymakers towards the predictors of current $\mathrm{CD}^{+}{ }^{+} \mathrm{T}$-cell count in women of reproductive age on ART and to develop strategies towards their immunological recovery. Moreover, knowing the predictors of $\mathrm{CD} 4^{+} \mathrm{T}$-cell count helps the programmers develop and implement strategies towards screening, early provision of treatment and prevention of major opportunistic infections, in order to reduce the morbidities and mortalities associated with advanced HIV disease. ${ }^{12,32}$ Thus, this study was aimed to assess the predictors of current $\mathrm{CD} 4^{+} \mathrm{T}$-cell count among women of reproductive age on antiretroviral therapy in public hospitals, southwest Ethiopia.

\section{Methods and Materials}

\section{Study Design and Period}

An institutional-based cross-sectional study design supported with record review was carried out at public hospitals in southwest Ethiopia from February 2018 to April 2018.

\section{Study Setting}

The study was carried out in three public hospitals of southwest Ethiopia: Mizan-Tepi University Teaching Hospital, Gebretsadik Shawo General Hospital and Tepi General Hospitals. These hospitals are located in BenchiMaji Zone, Kefa Zone, and Sheka Zone, respectively. Currently, Mizan-Tepi University Teaching Hospital is expected to provide service for more than 829,000 people. While Gebretsadik Shawo General Hospital and Tepi General Hospitals are expected to provide care for more than 500,000 people. ${ }^{33}$ The total number of HIV patients in Bench Maji Zone, Kaffa Zone, and Sheka Zone were 8913,3128 , and 4237, respectively, in 2018. At the time of data collection, there were 1776 (Bench Maji Zone), 849 (Kaffa Zone), and 1487 (Sheka zone) HIV clients on ART.

\section{Inclusion and Exclusion Criteria}

Women of reproductive age (15-49 years) who were on ART for at least 6 months and who had a baseline CD4+ T-cell count were included. Women who were critically ill, unable to give responses and blood specimens were excluded. Moreover, women who had incomplete secondary data records were excluded from the study.

\section{Sample Size Determination}

The sample size was calculated using a single population proportion formula $n=(Z \alpha / 2)^{2} p(1-p) / d^{2}$, where $n=$ was the sample size, $d=$ degree of precision $=0.05$; and $Z \alpha / 2$ $=1.96$ by assuming $95 \%$ confidence interval. Since there was not any research done in the study area, we took population proportion of $0.5(50 \%)$ to get the maximum sample size. Then, by adding $10 \%$ non-response rate, the final sample size was 422 .

\section{Sampling Procedure}

We applied a systematic random sampling method to select the study participants. First, 180, 120, and 150 women of reproductive age who were on ART per month werre taken from MTUTH, Bonga general Hospital, and Tepi General Hospital, respectively. Then, in the three months follow-up, a total of 1350 women of reproductive age who were on ART (540 from MTUTH, 360 from Bonga General Hospital, and 450 from Tepi General Hospital) were inspected for $\mathrm{VL}$ and $\mathrm{CD} 4^{+} \mathrm{T}$-cell count. Then, the sample sizes were proportionally allocated to each hospital (169 from MTUTH, 112 from Bonga General Hospital, and 141 from Tepi General Hospital). The sampling interval (kth) was calculated as the total number of women of reproductive age on ART follow-up during the data collection period divided by the sample size $(1350 / 422=3.19=3)$. Then every third participant was interviewed after the first eligible participant was selected by lottery method (Figure 1).

\section{Operational Definition}

Baseline data: refers to the laboratory and clinical data before initiation of ART.

Current $\mathrm{CD} 4^{+} \mathrm{T}$-cell count: refers to the $\mathrm{CD} 4^{+} \mathrm{T}$-cell count during the period of data collection.

Adherence: refers to starting ART treatment, keep all medical appointments, and taking drugs every day and exactly as prescribed. For this study, adherence was calculated as;

Adherance $=\frac{\text { No of doses of ART taken }}{\text { No of prescribed doses of ART }} \times 100 \%$, Finally, the result was categorized as; good adherence if $>95 \%$, fair adherence if $85-95 \%$, and poor adherence if $<85 \%$ of doses were taken. ${ }^{34-36}$

Immunological failure: was defined as persistent CD4 below 100 cells $/ \mathrm{mm}^{3}$, or a drop of CD4 cell count below baseline pre-treatment level, or a drop of CD4 cell count of $50 \%$ from the peak treatment value all in the absence of 
an ongoing co-infection and after a minimum of 6 months of ART. ${ }^{37}$

\section{Study Variables}

Dependent Variables

Current $\mathrm{CD}^{+}{ }^{+} \mathrm{T}$-cell count.

Independent Variables

Socio-demographic characteristics like; age, sex, residence, marital status, education, occupation, and other clinical characteristics like HIV/AIDS co-infection, baseline $\mathrm{CD}^{+} \mathrm{T}$-cell count, regimen type, WHO clinical staging, viral load, adherence, and duration of ART.

\section{Data Collection Tools and Procedure}

Data were collected by six trained health professionals' using structured questionnaires which were developed and adapted from reviewing different relevant literatures. ${ }^{38,39}$ Three health professionals' supervised the data collection process. The pretest was done among $5 \%$ of the sample size in health centers that were out of the study settings and then the coherence and skipping pattern of the questionnaire were corrected.

\section{Specimen Collection and Laboratory Procedure}

Upon completion of the questionnaire, about $5-8 \mathrm{~mL}$ of venous blood was collected from each patient on the same venipuncture for $\mathrm{CD}^{+}$T-cell count and viral load tests. After the whole blood was drawn, it was placed into two separate vacutainer tubes containing ethylene diamine tetra-acetic acid (EDTA) with anticoagulant (EDTA). About $3 \mathrm{~mL}$ of whole blood was used for $\mathrm{CD}^{+}{ }^{+} \mathrm{T}$-cell count. Centrifugation of the remaining $5 \mathrm{~mL}$ of whole blood was done for 20 minutes at $3000 \mathrm{rpm}$ and plasma was separated for the viral load test. Immediately the samples were stored at room temperature for $\mathrm{CD} 4{ }^{+} \mathrm{T}$-cell count and at $-80{ }^{\circ} \mathrm{C}$ for viral load testing and then processed within 24 hours and 5 hours, respectively.

Using the FACS Calibur flow cytometery (BD, CA, America), quantification of $\mathrm{CD} 4^{+} \mathrm{T}$-cell count was done. $\mathrm{CD}^{+}{ }^{+} \mathrm{T}$-cell count was done by adding $50 \mu \mathrm{L}$ whole blood to a reagent tube containing $20 \mu \mathrm{L}$ of monoclonal antibodies followed by vortexing and incubation for $30 \mathrm{~min}$ utes under dark conditions. Plasma viral load was measured using Quantitative Real-Time PCR HIV-1 assay by the COBAS $^{\circledR}$ AmpliPrep instrument (Roch, Homburg, Germany).

\section{Data Quality Assurance}

The quality of data was assured by using a pre-tested and properly designed questionnaire. Furthermore, the data collectors were trained on data and sample collection procedures.

The quality of the laboratory results was guaranteed by applying all quality control measures during sample collection and actual processing by following strict laboratory procedures. Standard operational procedures recommended by the manufacturers regarding centrifugation of whole blood, pipetting, transportation of samples, and aliquoting were strictly followed using standard protocol and laboratory bio-safety precautions.

\section{Data Processing and Analysis}

The data was entered using EPI INFO version 7 and exported to statistical packages for social science (SPSS) version 21.0 for data cleaning and analysis. Descriptive statistics such as mean, frequencies and percentages were used to summarize data. Bivariate and multiple regression analysis were done. Variables with p-values $<0.05$ were included in the multiple regression. The independent association between explanatory variables and current CD4 count was determined at $\mathrm{p}$ values $<0.05$.

\section{Results}

\section{Socio-Demographic Characteristics of the Respondents}

A total of 422 women of reproductive age on ART were enrolled in the study yielding a response rate of $100 \%$. The median (IQR) age of the participants was 37.00 (33.043.0) years. More than half $(290,68.7 \%)$ of the participants were urban residents, and $216(51.2 \%)$ were protestant religion followers. Of the total participants, nearly half $(196,46.4 \%)$ of them were currently married. Concerning the respondents' educational status, most $(159,37.7 \%)$ of them were illiterate (Table 1).

\section{Clinical Characteristics of Women of Reproductive Age on ART}

Women with HIV were on ART for the median (IQR) of 8 (610) years. At the baseline, more than half $(217,51.4 \%)$ of the respondents were on WHO clinical stage III, 257 (60.9\%) of them had $\mathrm{CD}^{+}$T-cell count of $<200$ cells $/ \mathrm{mm}^{3}$, and 354 (83.9\%) of them had good ARV drug adherence. During data collection time, the majority $(405,96 \%)$ of the participants were on WHO clinical stage II, and 174 (41.2\%) of them 


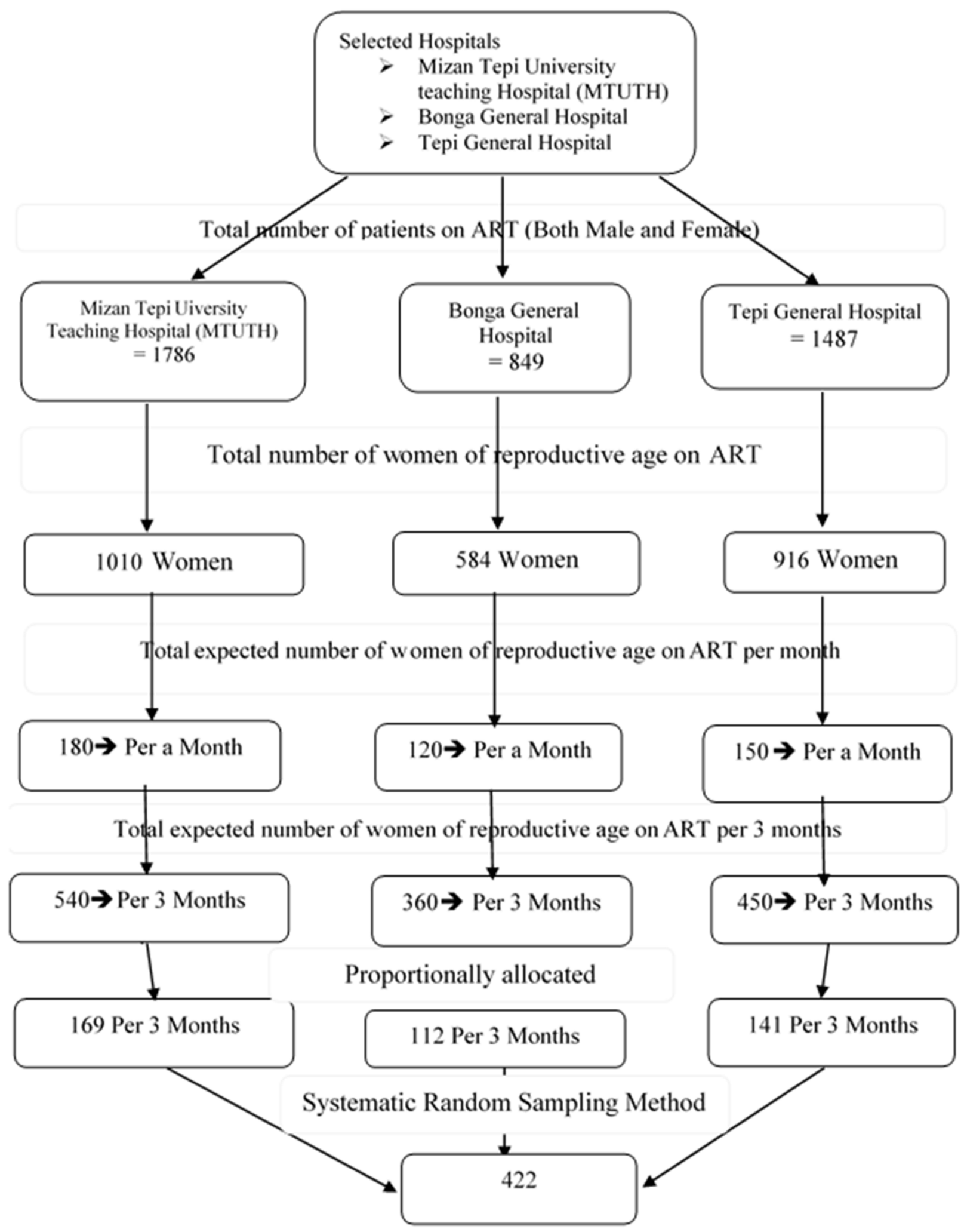

Figure I Schematic representation of the sampling procedure of HIV positive women of reproductive age on ART at the Public Hospitals from February Ist to April, 2018. 
had a CD4 $4^{+} \mathrm{T}$-cell count of $\geq 500$ cells $/ \mathrm{mm}^{3}$. Nearly half ( 180 , 42.7\%) of the participants switched ART regimens from firstline regimens to either other first-line regimens $(169,93.9 \%)$ or second-line regimens $(11,6.1 \%)$. The reasons for switching were mostly due to toxicity $(98,23.2 \%)$ followed by pregnancy $(33,7.8 \%)$ (Table 2).

\section{Results of Simple and Multiple Linear Regression Analysis}

The simple linear regression analysis revealed that residence, educational status, baseline WHO clinical stage, type of initial regimen, baseline adherence, opportunistic infection, baseline $\mathrm{CD}^{+}{ }^{+} \mathrm{T}$-cell count, viral load, and time duration on ART were significantly associated with current $\mathrm{CD}^{+}$T-cell count $(\mathrm{p}<0.05)$. Those variables were included in the multiple regression models.

In order to adjust for possible confounding factors, multiple linear regression analysis was applied after confirming that all assumptions were met. The relationship between the independent variables (IVs) and the current $\mathrm{CD}^{+}$T-cell count was linear. There was no multicollinearity of variables where variance inflation factor (VIF) scores fall between 1.092 and 1.943 indicated that it was below 10. The values of the residuals were independent or uncorrelated where the Durbin-Watson statistic was 1.978 indicating that the value was close to 2 not below 1 and above 3 . The variance of the residuals was constant or homoscedasticity was met where the variances of the current $\mathrm{CD}^{+}{ }^{+} \mathrm{T}$-cell counts were the same for all levels of the independent variables and the plot of standardized residuals versus standardized predicted values indicated that there were no signs of funneling. The normal P-P Plot indicated that the values of the residuals were normally distributed and there were no influential cases biasing the model where the Cook's distance values were all under 1 suggesting that no individual cases were likely to be significant outliers.

\section{Predictors of Current CD4+ T-Cell Count}

After adjusting for possible confounding factors using a multiple linear regression model considering all the above mentioned assumptions; educational status, baseline WHO clinical stage, type of initial regimen, baseline adherence, opportunistic infection, baseline $\mathrm{CD}^{+}{ }^{+}$T-cell count, viral load, and time duration on ART remained significantly associated with current $\mathrm{CD} 4^{+} \mathrm{T}$-cell count.
However, resident was not significantly associated with current $\mathrm{CD}^{+} \mathrm{T}$-cell count. This study finding indicated that about $44.7 \%$ of the variation in current $\mathrm{CD}^{+} \mathrm{T}$-cell count was explained by our model (R Square $=0.447$, P-value $<0.0001)$.

For each additional year a respondent stays on ART, the current $\mathrm{CD}^{+} \mathrm{T}$-cell count increased by 14.36 cells/ $\mathrm{mm}^{3}$ of blood $(\mathrm{p}<0.001)$. Similarly, for each increment of cells $/ \mathrm{mm}^{3}$ of blood in the baseline $\mathrm{CD} 4^{+} \mathrm{T}$-cell count, the current $\mathrm{CD}^{+} \mathrm{T}$-cell count increased by 0.354 cells $/ \mathrm{mm}^{3}$ of blood $(\mathrm{p}<0.0001)$. The current $\mathrm{CD} 4^{+} \mathrm{T}$-cell count of respondents whose educational status were certificate and above were higher than illiterate by 56.45 cells $/ \mathrm{mm}^{3}$ of blood ( $p<0.037$ ). The current $\mathrm{CD}^{+} \mathrm{T}$-cell count of women on ART who were on baseline WHO clinical stage II were higher than those who were on baseline WHO clinical stage III by 44.06 cells $/ \mathrm{mm}^{3}$ of blood $(\mathrm{p}=$ 0.026). Women of reproductive age on ART who took an initial regimen of $\mathrm{AZT}+3 \mathrm{TC}+\mathrm{EFV}$ had higher current $\mathrm{CD}^{+}$T-cell count than those who took $\mathrm{AZT}+3 \mathrm{TC}+\mathrm{NVP}$ by 167.23 cells $/ \mathrm{mm}^{3}$ of blood ( $p<0.0001$ ). The current $\mathrm{CD}^{+}$T-cell count of women of reproductive age on ART with poor adherence was less than those with good adherence by 181.06 cells $/ \mathrm{mm}^{3}$ of blood $(\mathrm{p}<0.0001)$. Similarly, the current $\mathrm{CD}^{+}{ }^{+} \mathrm{T}$-cell count of respondents who had opportunistic infections were less than their counterparts by 101.62 cells $/ \mathrm{mm}^{3}$ of blood $(\mathrm{p}<0.0001)$. Finally, respondents with a viral load of $\geq 1000$ copies $/ \mathrm{mm}^{3}$ had lower current $\mathrm{CD}^{+}{ }^{+} \mathrm{T}$-cell count than those respondents with an undetectable viral load by 137.53 copies $/ \mathrm{mm}^{3}$ ( $p<$ 0.01) (Table 3).

\section{Discussion}

Initiation of ART for women of reproductive age with HIV/AIDS is very crucial for the decrement of viral load in the blood, increment of $\mathrm{CD}^{+} \mathrm{T}$-cell count, and prevention of opportunistic infection. ${ }^{40,41}$ Understanding the factors determining the current $\mathrm{CD} 4^{+} \mathrm{T}$-cell count which in turn influences viral load in the blood is very critical for HIV-positive women to decide for the coming pregnancy and also it helps to develop integrated reproductive health care services. ${ }^{42,43}$ Thus this study aimed to assess the predictors of current CD4+ T-cell count among women of reproductive age on antiretroviral therapy attending public health hospitals in southwest Ethiopia.

In the current study, the immunological failure was found to be low as compared to the studies conducted in South Africa, $19.0 \%,{ }^{44}$ Tanzania, $17.1 \%,{ }^{45}$ southern 
Table I Socio-Demographic Characteristics of Women of Reproductive Age on ART $(n=422)$ in Public Hospitals, southwest Ethiopia, 2018

\begin{tabular}{|c|c|c|}
\hline Variables & Frequency & $\%$ \\
\hline \multicolumn{3}{|l|}{ Place of residence } \\
\hline Urban & 290 & 68.7 \\
\hline Rural & 132 & 31.3 \\
\hline \multicolumn{3}{|l|}{ Age of respondents } \\
\hline Median(IQR) in years & $37.00(33.0-43.0)$ & \\
\hline \multicolumn{3}{|l|}{ Marital status } \\
\hline Single & 64 & 15.2 \\
\hline Married & 196 & 46.4 \\
\hline Divorced & 108 & 25.6 \\
\hline Widowed & 54 & 12.8 \\
\hline \multicolumn{3}{|l|}{ Religion } \\
\hline Protestant & 216 & 51.2 \\
\hline Orthodox & 105 & 24.9 \\
\hline Muslim & 101 & 23.9 \\
\hline \multicolumn{3}{|l|}{ Ethnicity } \\
\hline Bench & 128 & 30.3 \\
\hline Oromo & 89 & 21.1 \\
\hline Amhara & 67 & 15.9 \\
\hline Kaffa & 40 & 9.5 \\
\hline Sheka & 36 & 8.5 \\
\hline Meini't & 35 & 8.3 \\
\hline Tigre & 16 & 3.8 \\
\hline Dizzi & II & 2.6 \\
\hline \multicolumn{3}{|c|}{ Respondent's educational status } \\
\hline Illiterate & 159 & 37.7 \\
\hline Primary & III & 26.3 \\
\hline Secondary & 94 & 22.3 \\
\hline Certificate and above & 58 & 13.7 \\
\hline \multicolumn{3}{|c|}{ Respondent's occupational status } \\
\hline Farmer & 31 & 7.3 \\
\hline Merchant & 44 & 10.4 \\
\hline Student & 12 & 2.8 \\
\hline Government employee & 31 & 7.3 \\
\hline Daily worker & 64 & 15.2 \\
\hline Housewife & 146 & 34.6 \\
\hline
\end{tabular}

Ethiopia, 20.3\%, ${ }^{46}$ and northern Ethiopia, 22\%. ${ }^{47}$ This might be due to the differences of the study population and study periods. For instance, the study subjects for the study conducted in southern Ethiopia were children.

In the current study, numbers of factors which are responsible for the reconstitution of the immune system of women of reproductive age with HIV were identified as independent predictors of the current $\mathrm{CD}^{+} \mathrm{T}$-cell count.
An increased current $\mathrm{CD} 4^{+} \mathrm{T}$-cell count in response to ART was observed among women with educational status of certificate and above compared to illiterate women. Similarly, participants with a high educational level had good immunological recovery, and are less prone to comorbidities associated to HIV infection in the studies conducted in KwaZulu-Natal, South Africa, ${ }^{48}$ and in India. ${ }^{49}$ This might be due to the fact that education may help HIV positive women be aware of the importance of early identification of their status of HIV/AIDS. Educated women may also have good adherence with ART drugs which will bring the reconstitution of the immune system and increment of current $\mathrm{CD} 4^{+} \mathrm{T}$-cell count.

The current $\mathrm{CD}^{+}{ }^{+}$T-cell counts of women on ART who were on baseline WHO clinical stage II were higher than those who were on baseline WHO clinical stage III. WHO reports revealed that early detection of HIV/AIDS and initiation of ART promotes an increased $\mathrm{CD}^{+}$T-cell count and a decreased viral load. ${ }^{18,50}$ Our finding is also supported by study findings in Uganda ${ }^{51}$ and Northern Ethiopia. ${ }^{52}$ Patients with advanced HIV status have poorer immunological recovery than those with early HIV status because opportunistic infections (OIs) are more common in patients with advanced HIV status. These OIs might contribute to the decrement of current $\mathrm{CD}^{+}$T-cell counts. ${ }^{53}$ Moreover, women with advanced HIV status commonly experience a decreased CD4 cell count, and this in turn means the women experience advanced HIV disease, which is at a high risk of death even after starting ART. ${ }^{12}$

The current study also revealed that women with an initial regimen of first-line ART drugs specifically AZT $+3 \mathrm{TC}+\mathrm{EFV}$ were significantly associated with increased $\mathrm{CD}^{+}$T-cell count. Consistent with the current study finding, a high immunological response among patients on $\mathrm{TDF} / 3 \mathrm{TC} / \mathrm{EFV}$ was also observed from a study conducted in Nepal. ${ }^{54}$ However, studies conducted in Europe ${ }^{55}$ and Ethiopia $^{52}$ indicated that the initial ART regimen class was not statistically significant with the immunologic response and CD4 count did not differ by ART regimen classes. This discrepancy might be due to sample size differences or due to biological characteristics. For instance, our study only focused on women of reproductive age, whereas the study conducted in Nepal include both sexes. ${ }^{54}$

The current $\mathrm{CD}^{+}{ }^{+} \mathrm{T}$-cell count of women of reproductive age on ART with poor adherence was less as compared with those with good adherence. Different studies conducted in China, ${ }^{56}$ Abidjan, Côte d'Ivoire, ${ }^{57}$ and 
Table 2 Clinical Characteristics of Women of Reproductive Age on ART in Public Hospitals, southwest Ethiopia, 2018

\begin{tabular}{|c|c|c|}
\hline Variables & Frequency & $\%$ \\
\hline Duration of HAART(years) & & \\
\hline$\leq 6$ & 117 & 27.7 \\
\hline$>6$ & 305 & 72.3 \\
\hline Median (IQR) of ART duration (In Years) & \multicolumn{2}{|c|}{$8(6-10)$} \\
\hline \multicolumn{3}{|l|}{ Baseline WHO clinical stage } \\
\hline I & 65 & 15.4 \\
\hline II & 152 & 36.0 \\
\hline III & 165 & 39.1 \\
\hline IV & 40 & 9.5 \\
\hline \multicolumn{3}{|l|}{ Baseline CD4 ${ }^{+}$T-cell count (cells $/ \mathrm{mm}^{3}$ ) } \\
\hline$<200$ & 257 & 60.9 \\
\hline $200-349$ & 128 & 30.3 \\
\hline $350-499$ & 26 & 6.2 \\
\hline$\geq 500$ & 11 & 2.6 \\
\hline \multicolumn{3}{|l|}{ Baseline ARV drug adherence } \\
\hline Good & 354 & 83.9 \\
\hline Fair & 35 & 8.3 \\
\hline Poor & 33 & 7.8 \\
\hline \multicolumn{3}{|l|}{ WHO stage during data collection } \\
\hline 1 & 13 & 3.1 \\
\hline II & 405 & 96 \\
\hline III & 4 & 0.9 \\
\hline \multicolumn{3}{|l|}{$\begin{array}{l}\mathrm{CD}^{+} \text {T-cell count during data collection (cells/ } \\
\mathrm{mm}^{3} \text { ) }\end{array}$} \\
\hline$<200$ & 32 & 7.6 \\
\hline $200-349$ & 96 & 22.7 \\
\hline $350-499$ & 120 & 28.5 \\
\hline$\geq 500$ & 174 & 41.2 \\
\hline \multicolumn{3}{|l|}{ Viral load count (copies/mm3) } \\
\hline Undetected & 233 & 55.2 \\
\hline $0-19$ & 79 & 18.7 \\
\hline 20-999 & 40 & 9.5 \\
\hline$\geq 1000$ & 70 & 16.6 \\
\hline \multicolumn{3}{|l|}{ Initial regimen } \\
\hline $\mathrm{d} 4 \mathrm{~T}+3 \mathrm{TC}+\mathrm{NVP}$ & 89 & 21.1 \\
\hline $\mathrm{d} 4 \mathrm{~T}+3 \mathrm{TC}+\mathrm{EFV}$ & 36 & 8.5 \\
\hline $\mathrm{AZT}+3 \mathrm{TC}+\mathrm{NVP}$ & 128 & 30.3 \\
\hline $\mathrm{AZT}+3 \mathrm{TC}+\mathrm{EFV}$ & 35 & 8.3 \\
\hline $\mathrm{TDF}+3 \mathrm{TC}+\mathrm{EFV}$ & 67 & 15.9 \\
\hline $\mathrm{TDF}+3 \mathrm{TC}+\mathrm{NVP}$ & 40 & 9.5 \\
\hline Pediatric (d4T +3TC+NVP) & 16 & 3.8 \\
\hline Pediatric 4C (AZT+3TC +NVP) & II & 2.6 \\
\hline \multicolumn{3}{|l|}{ Opportunistic Infection } \\
\hline No & 259 & 61.4 \\
\hline Yes & 163 & 38.6 \\
\hline
\end{tabular}

(Continued)
Table 2 (Continued).

\begin{tabular}{|l|r|r|}
\hline Variables & Frequency & $\%$ \\
\hline Switching & 242 & \\
No & 180 & 42.7 \\
Yes & & \\
\hline Switching drug Type & 169 & 93.9 \\
To Ist line drug & 11 & 6.1 \\
To 2nd line drug & & \\
\hline Second regimen & 62 & 14.7 \\
AZT+3TC+NVP & 32 & 7.6 \\
AZT+3TC+EFV & 26 & 6.2 \\
TDF+3TC+NVP & 47 & 11.1 \\
TDF+3TC+EFV & 13 & 3.1 \\
ABC+ddl+LPV/R & & \\
\hline Reasons for Switching Drug & 98 & 23.2 \\
Toxicity & 33 & 7.8 \\
Pregnancy & 24 & 5.7 \\
TB & 13 & 3.1 \\
Immunological failure & 7 & 1.7 \\
Default & 5 & 1.2 \\
Age & 368 & 87.2 \\
\hline Immunological Failure & 12.8 \\
No & 3 & 59.3 \\
Yes & 35.2 \\
\hline Components of Immunological Failure & & \\
CD4 Falling More Than 50\% & & \\
CD4 Falling Below Baseline & & \\
CD4 Persistently Below I00 cells/mm ${ }^{3}$ & & \\
\hline
\end{tabular}

Abbreviations: ARV, antiretroviral; EFV, efavirenz; TDF, tenofovir disoproxil fumarate; $d 4 T$, stavudine; 3TC, lamivudine; NVP, nevirapine; AZT, zidovudine; ABC, abacavir; ddl, didanosine; LPV/R, lopinavir/ritonavir.

University of Gondar Referral Hospital, northwest Ethiopia $^{21,58}$ revealed that adherence increased CD4 cells. Poor adherence to antiretroviral therapy (ART) may result in less effective viral suppression, poor immunological recovery, drug resistance, treatment side-effects, treatment failure, and subsequently reduced treatment options. ${ }^{59}$

In this study, the current $\mathrm{CD} 4^{+} \mathrm{T}$-cell count of respondents who had opportunistic infections was less than their counterparts. This finding is consistent with the studies conducted in the United States, ${ }^{60}$ Switzerland, ${ }^{61}$ and Saudi Arabia. ${ }^{62}$ Depletion of $\mathrm{CD}^{+}$cells may leads to cellular and subsequently humoral deficiencies. These deficiencies may in turn bring HIV-related OIs which are usually contributing factors for the $\mathrm{CD}^{+} \mathrm{T}$-cell count falling below 200/mm ${ }^{3}{ }^{60,63}$ Depleted $\mathrm{CD} 4^{+}$T-cell count 


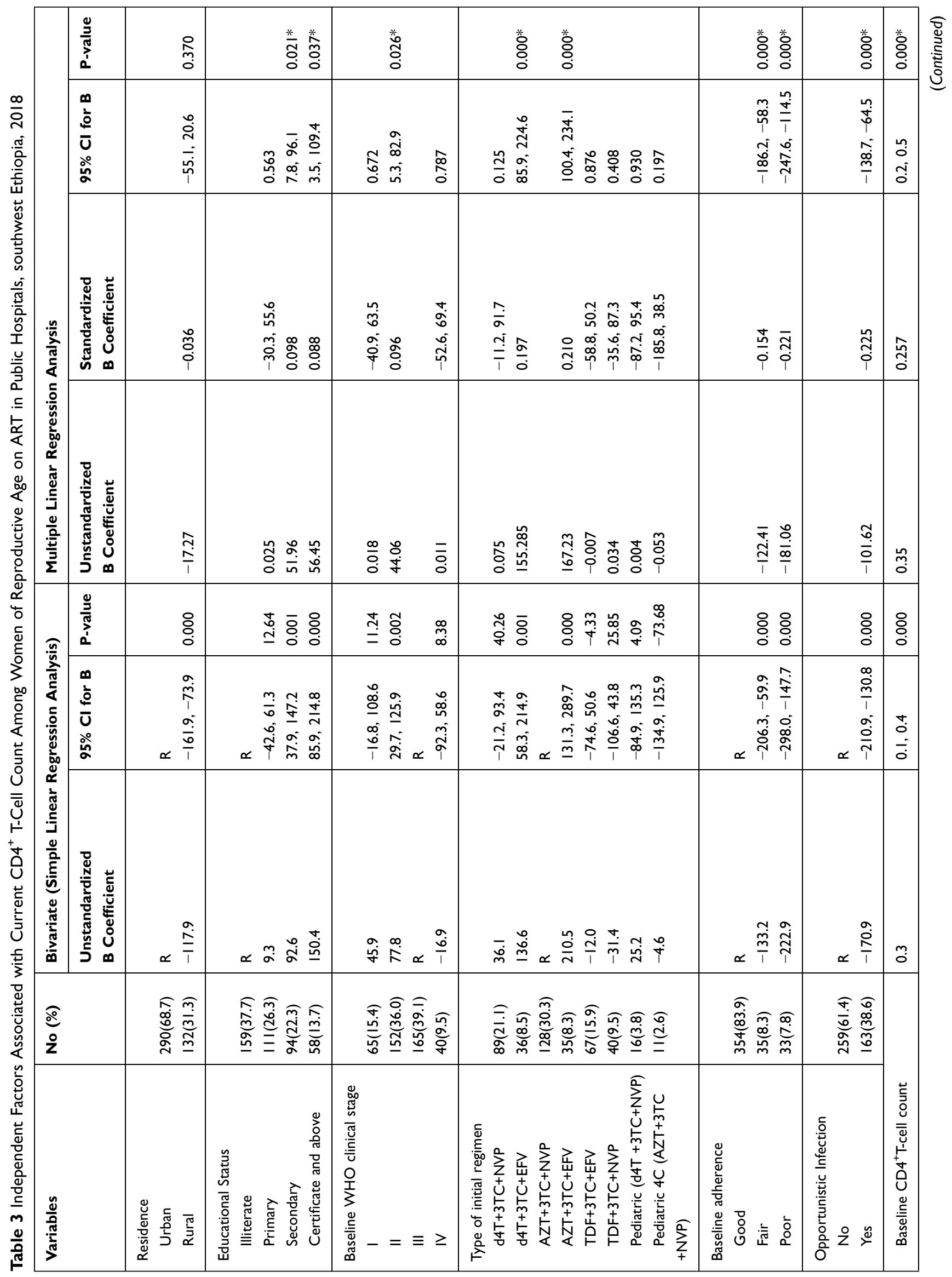




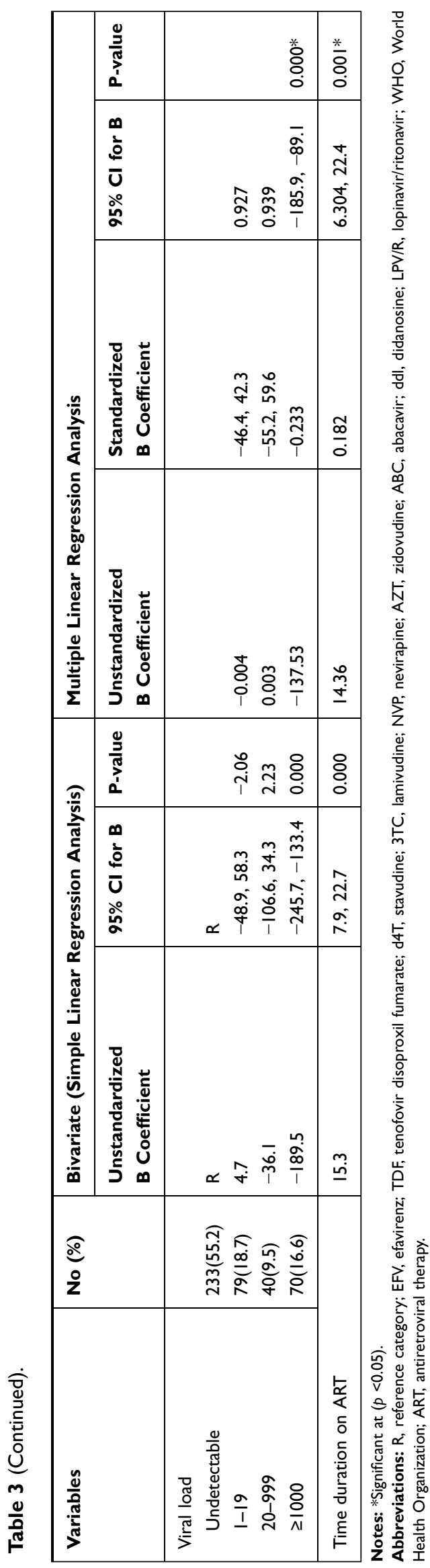

is also a key factor to determine both the urgency of ART initiation and provision of prophylaxis for opportunistic infections. ${ }^{64}$

In this study, viral load was also found to be a significant predictor for the current $\mathrm{CD} 4^{+} \mathrm{T}$-cell count where women on ART with a viral load of $\geq 1000$ copies/ $\mathrm{mm}^{3}$ had lower current $\mathrm{CD} 4^{+}$T-cell count than those women with undetectable viral load. This finding agrees with other studies conducted in London ${ }^{25}$ and Nepal. ${ }^{54}$ These studies showed that maintaining virological suppression resulted in the restoration of current $\mathrm{CD}^{+}$ T-cell counts. ${ }^{25,54}$ Moreover, ongoing HIV replication during treatment can lead to immunological failure, the emergence of drug resistance, limiting future treatment options, and possibly leading to a poorer prognosis. ${ }^{65}$

Duration on ART was also a significant predictor for current $\mathrm{CD}^{+}{ }^{+} \mathrm{T}$-cell count, where for each additional year stay on ART, the current $\mathrm{CD}^{+}{ }^{+}$T-cell count increased. This study is consistent with a study conducted in Yaounde, Cameroon. ${ }^{66}$ This could be explained by which the importance of maintaining virologic control and immunological recovery is based on the current status of HIV pathogenesis, in which continuous and uninterrupted ART regimen is needed to suppress viral replication, reconstitute the immune system and prevent disease progression. ${ }^{67,68}$

In the current study, baseline $\mathrm{CD} 4^{+} \mathrm{T}$-cell count was found to be significant, where for each increment of cells/ $\mathrm{mm}^{3}$ of blood in the baseline $\mathrm{CD}^{+}$T-cell count, the current $\mathrm{CD}^{+} \mathrm{T}$-cell count increased. This finding is consistent with studies conducted in Felege Hiwot referral hospital, ${ }^{22}$ University of Gondar referral hospital, ${ }^{21,69}$ and Tigray Health Research Institute. ${ }^{23}$

The results of the current study have some limitations. First, since a retrospective cross-sectional study design was implemented, it cannot establish a cause and effect relationship between the predictor variables and dependent variable (current $\mathrm{CD}^{+}{ }^{+}$T-cell count). Second, the viral load test was not routinely performed in all public health hospitals because of the unavailability of the test. Despite these limitations, the result of this study may provide important information which will certainly be useful as an input for the HIV/ART programs.

\section{Conclusion}

In this study, the immunological failure was relatively low. Educational status, baseline WHO clinical stage, type of initial regimen, baseline adherence, opportunistic 
infection, baseline $\mathrm{CD}^{+}{ }^{+}$T-cell count, viral load, and time duration on ART were significantly associated with current $\mathrm{CD}^{+}$T-cell count. Therefore, maintaining adherence, early identification and treatment of opportunistic infections, and minimizing viral load to undetectable levels may further decrease immunological failure.

\section{Abbreviations}

ABC, abacavir; AIDS, acquired immune deficiency syndromes; ART, antiretroviral therapy; ARV, antiretroviral virus; AZT/3TC, zidovudine/lamivudine; CD4, cluster of differentiation 4; DDI, didanosine; EFV, efavirenz; HIV, human immune deficiency virus; LPV/R, lopinavir/ritonavir; NVP, nevirapine; OI, opportunistic infection; SOP, standard operational procedures; TDF, tenofovir disoproxil fumarate; VL, viral load.

\section{Data Sharing Statement}

All relevant data are included within the manuscript, but any additional data required are available from the corresponding author upon request. Email: Alex.sayihalem2018@gmail.com.

\section{Ethics Approval and Consent to Participate}

This study was conducted in accordance with the Declaration of Helsinki and after ethical clearance was obtained from the research directorate office of Mizan Tepi University (Ref No: MTU/CHS/12/342/12/08). Written consent was obtained from each study participant after explaining the purpose and objectives of the study. For those participants who were illiterate, a fingerprint was used as a signature after trained interviewers have carefully explained the purpose, benefits, and potential risks before consent were obtained. The interview with study participants was conducted with strict privacy and confidentiality. The test was also performed following the manufacturer's instructions and interpreted accordingly. Then, all necessary information and the results of each study participant were communicated with their physicians for further investigations and management.

\section{Acknowledgment}

We would like to thank the Department of Medical Laboratory Science, College of Medicine and Health Science, Mizan-Tepi University for giving us this chance to conduct this research.

\section{Author Contributions}

All authors made a significant contribution to the work reported, whether that is in the conception, study design, execution, acquisition of data, analysis and interpretation, or in all these areas; took part in drafting, revising or critically reviewing the article; gave final approval of the version to be published; have agreed on the journal to which the article has been submitted; and agree to be accountable for all aspects of the work.

\section{Funding}

Funding for this study was made possible through grants offered by Mizan Tepi University.

\section{Disclosure}

We declare that we have no conflict of interests.

\section{References}

1. UNAIDS. Global HIV \& AIDS statistics - 2020 fact sheet. 2020; Available from: https://www.unaids.org/en/resources/fact-sheet. Accessed November 6, 2020.

2. AmfAR. Statistics: women and HIV/AIDS. 2020; Available from: https://www.amfar.org/about-hiv-and-aids/facts-and-stats/statisticswomen-and-hiv-aids/. Accessed May 13, 2021.

3. Charles M, Boyle B. Excess and access: the continuing controversy regarding HIV and health care in Africa. AIDS Read. 2002;12(7):288.

4. UNAIDS. UNAIDS country director, Ethiopia - eligibility to apply limited; check additional information*; 2020; Available from: https:/ erecruit.unaids.org/public/hrd-cl-vac-view.asp?o_c=1000\&jobinfo_ uid_c=36610\&vaclng=en. Accessed June 1, 2021.

5. UNAIDS. Ethiopia|UNAIDS; 2020. Available from: https://www.unaids. org/en/regionscountries/countries/ethiopia. Accessed November 6, 2020.

6. Health NIo. What is HAART? | National Institute on Drug Abuse (NIDA); 2020. Available from: https://www.drugabuse.gov/publica tions/research-reports/hivaids/what-haart. Accessed November 5, 2020

7. CDC. HIV treatment; 2020. Available from: https://www.cdc.gov/ hiv/basics/livingwithhiv/treatment.html. Accessed May 12, 2021.

8. World Health Organization. Guideline on when to start antiretroviral therapy on pre-exposure prophylaxis for HIV; 2015. Available from: https://www.who.int/hiv/pub/guidelines/earlyrelease-arv/en/. Accessed June 1, 2021

9. Glass TR, Motaboli L, Nsakala B, et al. The viral load monitoring cascade in a resource-limited setting: a prospective multicentre cohort study after introduction of routine viral load monitoring in rural Lesotho. PLoS One. 2019;14(8):e220337. doi:10.1371/journal. pone. 0220337

10. Lecher S, Williams J, Fonjungo PN, et al. Progress with scale-up of HIV viral load monitoring - seven sub-Saharan African countries, January 2015-June 2016. Morbid Mortal Wkly Rep. 2016;65 (47):1332-1335. doi:10.15585/mmwr.mm6547a2

11. Roberts T, Cohn J, Bonner K, Hargreaves S. Scale-up of routine viral load testing in resource-poor settings: current and future implementation challenges. Clin Infect Dis. 2016;62(8):1043-1048. doi:10.1093/ $\mathrm{cid} / \mathrm{ciw} 001$

12. World Health Organization. Guidelines for managing advanced HIV disease and rapid initiation of antiretroviral therapy, July 2017. 2017. 
13. Foundation EGPA. Advanced HIV disease and opportunistic infection; 2021. Available from: https://www.pedaids.org/ourexpertise/advanced-hiv-disease-and-opportunistic-infection/. Accessed June 1, 2021.

14. SinoBiological. Cluster of differentiation 4/CD4. 2021. Available from: https://www.sinobiological.com/research/cd-antigens/cluster-of -differentiation-4. Accessed May 15, 2021.

15. No A. What's new in treatment monitoring: viral load and CD4 testing. Update. 2017.

16. Ford N, Meintjes G, Pozniak A, et al. The future role of CD4 cell count for monitoring antiretroviral therapy. Lancet Infect Dis. 2015;15(2):241-247. doi:10.1016/S1473-3099(14)70896-5

17. Masur H, Brooks JT, Benson CA, Holmes KK, Pau AK, Kaplan JE. Prevention and treatment of opportunistic infections in HIV-infected adults and adolescents: updated guidelines from the Centers for Disease Control and Prevention, National Institutes of Health, and HIV Medicine Association of the Infectious Diseases Society of America. Clin Infect Dis. 2014;58(9):1308-1311. doi:10.1093/cid/ciu094

18. World Health Organization. WHO Case Definitions of HIV for Surveillance and Revised Clinical Staging and Immunological Classification of HIV-Related Disease in Adults and Children. World Health Organization; 2007.

19. Bennett DE, Myatt M, Bertagnolio S, Sutherland D, Gilks CF. Recommendations for surveillance of transmitted HIV drug resistance in countries scaling up antiretroviral treatment. Antivir Ther. 2008;13:25.

20. Ayele G, Tessema B, Amsalu A, Ferede G, Yismaw G. Prevalence and associated factors of treatment failure among HIV/AIDS patients on HAART attending University of Gondar Referral Hospital Northwest Ethiopia. BMC Immunol. 2018;19(1):37. doi:10.1186/ s12865-018-0278-4

21. Manaye GA, Abateneh DD, Kebede KM, Belay AS. Immunological response during HAART and determinants of current CD4+ T-cell count among HIV/AIDS patients attending University of Gondar Referral Hospital, Northwest Ethiopia. HIV/AIDS (Auckland, NZ). 2020;12:295.

22. Gezie LD. Predictors of CD4 count over time among HIV patients initiated ART in Felege Hiwot Referral Hospital, northwest Ethiopia: multilevel analysis. BMC Res Notes. 2016;9(1):1-9. doi:10.1186/ s13104-016-2182-4

23. Desta AA, Wubayehu Woldearegay T, Berhe AA, Futwi N, Gebremedhn Gebru G, Godefay H. Immunological recovery, failure and factors associated with CD-4 T-cells progression over time, among adolescents and adults living with HIV on antiretroviral therapy in northern Ethiopia: a retrospective cross sectional study. PLoS One. 2019;14(12):e0226293. doi:10.1371/journal.pone.0226293

24. Ebonyi AO, Agbaji OO, Anejo-Okopi JA, et al. Factors associated with a low CD4 count among HIV-1 infected patients at enrolment into HAART in Jos, Nigeria. Br J Med Med Res. 2014;4 (13):2536-2545. doi:10.9734/BJMMR/2014/8469

25. Smith CJ, Sabin CA, Youle MS, et al. Factors influencing increases in CD4 cell counts of HIV-positive persons receiving long-term highly active antiretroviral therapy. $J$ Infect Dis. 2004;190(10):1860-1868. doi:10.1086/425075

26. Florence E, Lundgren J, Dreezen C, et al. Factors associated with a reduced CD4 lymphocyte count response to HAART despite full viral suppression in the EuroSIDA study. HIV Med. 2003;4 (3):255-262. doi:10.1046/j.1468-1293.2003.00156.x

27. Farhadian M, Mohammadi Y, Mirzaei M, Shirmohammadi-Khorram N. Factors related to baseline CD4 cell counts in HIV/AIDS patients: comparison of poisson, generalized poisson and negative binomial regression models. BMC Res Notes. 2021;14(1):1-7. doi:10.1186/ s13104-021-05523-w

28. Montarroyos UR, Miranda-Filho DB, César CC, et al. Factors related to changes in $\mathrm{CD} 4+\mathrm{T}$-cell counts over time in patients living with HIV/AIDS: a multilevel analysis. PLoS One. 2014;9(2):e84276. doi:10.1371/journal.pone. 0084276
29. Akinbami AA, Gbadegesin A, Ajibola SO, et al. Factors influencing CD4 cell count in HIV-positive pregnant women in a secondary health center in Lagos, Nigeria. HIV/AIDS (Auckland, NZ). 2015;7:115.

30. Bruneau L, Billaud E, Raffi F, Hanf M. Factors associated with the level of CD4 cell counts at HIV diagnosis in a French cohort: a quantile regression approach. Int $J$ STD AIDS. 2017;28 (4):397-403. doi:10.1177/0956462416650980

31. Seyoum A, Zewotir T, Zewotir T. Quasi-poisson versus negative binomial regression models in identifying factors affecting initial CD4 cell count change due to antiretroviral therapy administered to HIV-positive adults in North-West Ethiopia (Amhara region). AIDS Res Ther. 2016;13(1):1-10. doi:10.1186/s12981-016-0119-6

32. Helleberg M, Kronborg G, Larsen CS, et al. CD4 decline is associated with increased risk of cardiovascular disease, cancer, and death in virally suppressed patients with HIV. Clin Infect Dis. 2013;57 (2):314-321. doi:10.1093/cid/cit232

33. CSA. Population and housing census 2007 report, SNNPR, part I: population size and characteristics; 2007 Available from: https:// microdata.worldbank.org/index.php/catalog/2747/related-materials. Accessed March 21, 2021.

34. NACO. National guidelines on second-line ART for adults and adolescents. 2013. Available from: http://naco.gov.in/sites/default/ files/National $\% 20$ Guidelines $\% 20$ on $\% 20$ Second-line $\% 20$ and $\%$ 20Alternative $\% 20$ First-line $\% 20$ ART $\% 20$ For $\% 20$ Adults $\% 20$ and $\%$ 20Adolescents\%20May\%202013_0.pdf. Accessed June 1, 2021.

35. World Health Organization. March 2014 supplement to the 2013 consolidated guidelines on the use of antiretroviral drugs for treating and preventing HIV infection: recommendations for a public health approach. 2014

36. Delhi N. Department of AIDS control, national AIDS control organisation, ministry of health and family welfare, Government of India; 2012. Curr Epidemiol Situation HIV/AIDS Ann Rep. 2011;12.

37. Reynolds SJ, Nakigozi G, Newell K, et al. Failure of immunologic criteria to appropriately identify antiretroviral treatment failure in Uganda. AIDS (London, England). 2009;23(6):697. doi:10.1097/ QAD.0b013e3283262a78

38. Ayalew MB, Kumilachew D, Belay A, et al. First-line antiretroviral treatment failure and associated factors in HIV patients at the University of Gondar Teaching Hospital, Gondar, Northwest Ethiopia. HIV/AIDS (Auckland, NZ). 2016;8:141.

39. Bokretsion GB, Endalkachew N, Getachew KA. HIV/AIDS treatment failure and its determinant factors among first line HAART patients at Felege-Hiwot Referral Hospital, Bahir Dar, Northwest Ethiopia. J AIDS Clin Res. 2017;8(11).

40. Matthews LT, Crankshaw T, Giddy J, et al. Reproductive decision-making and periconception practices among HIV-positive men and women attending HIV services in Durban, South Africa. AIDS Behav. 2013;17(2):461-470. doi:10.1007/ s10461-011-0068-y

41. Kaida A, Laher F, Strathdee SA, et al. Childbearing intentions of HIV-positive women of reproductive age in Soweto, South Africa: the influence of expanding access to HAART in an HIV hyperendemic setting. Am $J$ Public Health. 2011;101(2):350-358. doi:10.2105/AJPH.2009.177469

42. Kisakye P, Akena WO, Kaye DK. Pregnancy decisions among HIV-positive pregnant women in Mulago Hospital, Uganda. Cult Health Sex. 2010;12(4):445-454. doi:10.1080/13691051003628922

43. King R, Khana K, Nakayiwa S, et al. 'Pregnancy comes accidentallylike it did with me': reproductive decisions among women on ART and their partners in rural Uganda. BMC Public Health. 2011;11 (1):530. doi:10.1186/1471-2458-11-530

44. El-Khatib Z, Katzenstein D, Marrone G, et al. Adherence to drug-refill is a useful early warning indicator of virologic and immunologic failure among HIV patients on first-line ART in South Africa. PLoS One. 2011;6(3):e17518. doi:10.1371/journal.pone.0017518 
45. Jaka H, Mshana S, Liwa A, Peck R, Kalluvya S. Prevalence of immunological failure and durability of first line antiretroviral therapy at Bugando Hospital Mwanza, Tanzania. Tanzan Med J. 2009;24(2).

46. Bacha T, Tilahun B, Worku A. Predictors of treatment failure and time to detection and switching in HIV-infected Ethiopian children receiving first line anti-retroviral therapy. BMC Infect Dis. 2012;12 (1):1-8. doi:10.1186/1471-2334-12-197

47. Assefa A, Gelaw B, Getnet G, Yitayew G. The effect of incident tuberculosis on immunological response of HIV patients on highly active anti-retroviral therapy at the university of Gondar hospital, northwest Ethiopia: a retrospective follow-up study. BMC Infect Dis. 2014;14(1):1-8. doi:10.1186/1471-2334-14-468

48. Dessie ZG, Zewotir T, Mwambi H, North D. Modelling of viral load dynamics and CD4 cell count progression in an antiretroviral naive cohort: using a joint linear mixed and multistate Markov model. BMC Infect Dis. 2020;20:1-14. doi:10.1186/s12879-020-04972-1

49. Maurya S, Singh R, Negi N, Kapil A, Chaudhry R, Das B. The level of education affects CD4 cell count and wellness among HIV infected adult between age group 18 to 60 years. Int J Infect Dis. 2016;45:264. doi:10.1016/j.ijid.2016.02.589

50. Weinberg JL, Kovarik CL. The WHO clinical staging system for HIV/AIDS. AMA J Ethics. 2010;12(3):202-206.

51. Kagaayi J, Makumbi F, Nakigozi G, et al. WHO HIV clinical staging or CD4 cell counts for antiretroviral therapy eligibility assessment? An evaluation in rural Rakai district, Uganda. Aids. 2007;21 (9):1208-1210. doi:10.1097/QAD.0b013e32810c8dce

52. Sorsa A. Clinical, immunological and virological responses of zidovudine-lamivudine-nevirapine versus zidovudine-lamivudineefavirenz antiretroviral treatment (ART) among HIV-1 infected children: Asella Teaching and Referral Hospital, South-East Ethiopia. Open Med Inform J. 2018;12:11. doi:10.2174/1874431101812010011

53. Desta AA, Kidane KM, Bahta YW, et al. Determinants of immunological recovery following HAART among severely immunosuppressed patients at enrolment to care in Northern Ethiopia: a retrospective study. BMJ Open. 2020;10(8):e038741. doi:10.1136/ bmjopen-2020-038741

54. Ojha CR, Shakya G, Dumre SP. Virological and immunological status of the people living with HIV/AIDS undergoing ART treatment in Nepal. Biomed Res Int. 2016;2016:1-7. doi:10.1155/2016/6817325

55. Waters L, Stebbing J, Jones R, et al. A comparison of the CD4 response to antiretroviral regimens in patients commencing therapy with low CD4 counts. J Antimicrob Chemother. 2004;54(2):503-507. doi:10.1093/jac/dkh329

56. Wang H, Zhou J, He G, et al. Consistent ART adherence is associated with improved quality of Life, CD4 counts, and reduced hospital costs in central China. AIDS Res Hum Retroviruses. 2009;25 (8):757-763. doi:10.1089/aid.2008.0173

57. Abrogoua DP, Kablan BJ, Kamenan BAT, Aulagner G, N'Guessan K, Zohoré C. Assessment of the impact of adherence and other predictors during HAART on various CD4 cell responses in resource-limited settings. Patient Prefer Adherence. 2012;6:227. doi:10.2147/PPA.S26507
58. Molla AA, Gelagay AA, Mekonnen HS, Teshome DF. Adherence to antiretroviral therapy and associated factors among HIV positive adults attending care and treatment in University of Gondar Referral Hospital, Northwest Ethiopia. BMC Infect Dis. 2018;18 (1):266. doi:10.1186/s12879-018-3176-8

59. Williams PL, Storm D, Montepiedra G, et al. Predictors of adherence to antiretroviral medications in children and adolescents with HIV infection. Pediatrics. 2006;118(6):e1745-e1757. doi:10.1542/peds.2006-0493

60. Lipshultz SE, Easley KA, Orav EJ, et al. Cardiac dysfunction and mortality in HIV-infected children: the prospective P2C2 HIV multicenter study. Circulation. 2000;102(13):1542-1548. doi:10.1161/01.CIR.102.13.1542

61. Sudano I, Spieker LE, Noll G, Corti R, Weber R, Lüscher TF. Cardiovascular disease in HIV infection. Am Heart J. 2006;151 (6):1147-1155. doi:10.1016/j.ahj.2005.07.030

62. Buba F. Cardiovascular opportunistic infections in HIV disease. 2011.

63. Williams I, Churchill D, Anderson J, et al. British HIV Association guidelines for the treatment of HIV-1-positive adults with antiretroviral therapy 2012 (Updated November 2013. All changed text is cast in yellow highlight). HIV Med. 2014;15:1-85. doi:10.1111/hiv.12119

64. Okoye AA, Picker LJ. CD 4+ T-cell depletion in HIV infection: mechanisms of immunological failure. Immunol Rev. 2013;254 (1):54-64. doi:10.1111/imr.12066

65. Carter M. Any reduction in viral load has immunologic benefits for people with HIV who have triple-class treatment failure; 2013. Available from: https://www.aidsmap.com/news/jan-2013/anyreduction-viral-load-has-immunologic-benefits-people-hiv-who-havetriple-class. Accessed November 23, 2020.

66. Fokam J, Billong SC, Jogue F, et al. Immuno-virological response and associated factors amongst HIV-1 vertically infected adolescents in Yaoundé-Cameroon. PLoS One. 2017;12(11):e0187566. doi:10.1371/journal.pone.0187566

67. Zhang L, Ramratnam B, Tenner-Racz K, et al. Quantifying residual HIV-1 replication in patients receiving combination antiretroviral therapy. $N$ Engl J Med. 1999;340(21):1605-1613. doi:10.1056/ NEJM199905273402101

68. Finzi D, Blankson J, Siliciano JD, et al. Latent infection of CD4+ $\mathrm{T}$ cells provides a mechanism for lifelong persistence of HIV-1, even in patients on effective combination therapy. Nat Med. 1999;5 (5):512-517. doi:10.1038/8394

69. Kokeb M, Degu G. Immunological response of HIV-infected children to highly active antiretoviral therapy at Gondar university hospital, north-western Ethiopia. Ethiop $J$ Health Sci. 2016;26(1):25-30. doi:10.4314/ejhs.v26i1.6
HIV/AIDS - Research and Palliative Care

\section{Publish your work in this journal}

HIV/AIDS - Research and Palliative Care is an international, peerreviewed open-access journal focusing on advances in research in HIV, its clinical progression and management options including antiviral treatment, palliative care and public healthcare policies to control viral spread. The manuscript management system is completely online and includes a very quick and fair peer-review system, which is all easy to use. Visit http://www.dovepress.com/testimonials.php to read real quotes from published authors. 